\title{
MEASURING THE EFFECT OF THE SOLID WASTE EDUCATION FOR SUSTAINABILITY AT ELEMENTARY SCHOOLS IN DA NANG CITY, VIETNAM
}

\author{
Phan Hoang Thu Thao and Takaaki Kato
}

\begin{abstract}
Environmental education provides people with knowledge about the biophysical environment and its associated problems. Environmental education of children (ages 6-12) can be used as key inputs to increase environmentally friendly activities associated with solid waste treatment in Vietnam, as it is not systematically done in the country. This study aims to measure the effects of environmental education, which consist of knowledge of environmental problems due to improper treatment of waste as well as the benefits of recycling at two elementary schools in Da Nang City, Vietnam.

In March 2015 three hundred and ten 5th grade students were randomly separated into 2 treatment groups. Group 1 had an activity with a game and group 2 had an activity without the game. Afterward students could participate in (1) a garbage separation game, (2) a seminar to learn the present status of eco-bag systems and voluntary food residue recycling in Da Nang city, and (3) a questionnaire survey to assess the impacts of the environmental education. The results show that students had limited knowledge about the characteristics of eco-bag (29\%) and plastic bag (55\%). After environmental education activities, students' correct answers increased as: eco-bag (87\%), plastic bag (71\%), food waste $(93 \%)$, and food waste recycling systems $(87 \%)$. However, there was no difference from the questionnaire results between the 2 treatment groups.
\end{abstract}

Based on the results, an environmental education program should be developed in the schools to improve the future of solid waste management in Vietnam.

\section{KEYWORD:}

Environmental education; Waste education

\section{INTRODUCTION}

An increase in waste generation due to a rising population has become a challenge for many developing countries, including Vietnam, as governments fight to establish proper municipal solid waste (MSW) management protocols. Poor waste management is a growing and common problem faced by developing countries. Recently, Vietnam has faced great challenges in solid waste management including not only the collection, transfer, and final disposal of waste, but also a lack of public awareness of the solid waste system, haphazard urbanization, the introduction of environmentally unfriendly materials, and changing consumption patterns. With a total area of 331,210 $\mathrm{km}^{2}$ Vietnam is one of the most populated countries in Southeast Asia. In July 2015, its population was estimated to be approximately 94 million; and its population growth rate was $0.97 \%$. Approximately $33.6 \%$ of the country's residents currently live in the cities with an urbanization rate of $2.95 \%$ annually [1]. Therefore solid waste is a growing problem in Vietnam, especially in big cities with rapid increasing populations. The country produces more than 15 million tons of waste each year, and this volume is expected to grow rapidly over the next decade. Urban areas produce more than $80 \%$ (12.8 million tons/year) of the country's municipal solid waste. Solid waste in urban areas mainly consists of food waste, paper, plastic, wood, metal, and glass, with some hazardous household waste such as flashlights, bulbs and batteries [2]. Currently there is no effective mechanism of publicly organized recycling. The government has been trying to implement a waste separation and recycling policy throughout the country but has not yet succeeded mainly due to a lack of funding and human resources in the public sector [3].

Da Nang is one of the major port cities in Vietnam (in addition to Ho Chi Minh City and Haiphong) and is the biggest city on the South Central Coast. It is listed as a first class city and has a higher urbanization ratio than any other centrally governed cities. The administrative area of the city is composed of 6 urban districts and 2 suburban districts; one of these is a suburban island with an area of $305 \mathrm{~km}^{2}$. The total area of Da Nang is $1285.43 \mathrm{~km}^{2}$. The population of 
the city is 951,684 with a large number of people traveling in from other municipalities to work. The population density is 740.36 persons per $\mathrm{km}^{2}$. From 2002 to 2011 the population in Da Nang increased approximately 1.3 times [4].

According to a Da Nang URENCO (the agency responsible for solid waste collection in $\mathrm{Da}$ Nang city) report, an average of $700-750$ tons of MSW was collected per day and disposed at the Khanh Son Landfill. This represents a collection rate of $90 \%$ in 2012 [5]. From information provided by the Japan International Cooperation Agency (JICA) in a report to Vietnam Ministry of Natural Resources and Environment, the composition of MSW in Da Nang is $68.47 \%$ food waste, $5.07 \%$ paper, $2.89 \%$ cloth, $2.79 \%$ wood, $11.36 \%$ plastic, $0.14 \%$ glass, $1.45 \%$ metal, $0.02 \%$ hazardous waste and $3.15 \%$ other waste [6]. With its designed capacity, the Khanh Son Landfill will reach its limit by 2020 at current waste generating rates. Therefore in Da Nang, there is an urgent need for reduction, reuse and recycling measures of MSW. Recently, there are some projects on sustainable development in solid waste management, such as: eco-city project at Cam Le District, Da Nang, and Compost plant - agricultural waste at Hoa Vang suburban district [5]. In addition, there is a food waste collection system where farmers collect and use food waste to feed pigs $[6,7,8]$.

Many MSW education projects have started in many Southeast Asia countries, such as: School Waste Bank in Thailand [11], community-based waste management in Surabaya, Indonesia [10], and $3 \mathrm{R}$ project in Ha Noi, Vietnam [9]. There are growing needs for solid waste education for children in developing countries of Southeast Asia as shown in Table 1. However, solid waste education for young children is limited in its application in most countries of this region. In particular, education for solid waste treatment is rarely done in elementary schools in Vietnam.

Long-term environmental education is a good system to increase students' awareness of the environment, such as: Early Childhood Care \& Education in New Brunswick, Canada [12]; working towards sustainable schooling in Gothenburg, Sweden [13] and learning and ecological activities in Nishinomiya, Japan [14]. Building long-term environmental education always requires a long time and a corresponding budget. In developing countries with serious environmental problems, long-term environmental education will not be suitable systems. With low cost and time, shortterm education is becoming a good solution for environmental problems in developing countries. Vietnam does not have any regular program to teach the students about solid waste management. Vietnam had done some small MSW projects in some big cities, such as: 3Rs project in Ha Noi city. This project had some environmental education classes for university students who were interested in environmental protection. This project was implemented for 3 years, from November 2006 to November 2009, in four districts in Ha Noi, which were selected to conduct a pilot project on source separation of biodegradable waste and production of organic fertilizer. As a pilot project with the source separation of biodegradable waste in the selected model districts, a suitable new waste collection system for collecting source-separated waste was introduced instead of a traditional one. Under the new collection system, citizens have to separate biodegradable waste to a green-coloured bin and others to an orange-coloured bin from six to eight o'clock at night at designated sites. The project has succeeded by involving a variety of stakeholders in the process of implementation with the source separation, composting, environmental education and raising citizens' awareness [15]. However, the 3Rs project in $\mathrm{Ha}$ Noi is not an appropriate model to be applied in other cities in Vietnam. For example, Da Nang city does not have a composting plant neither is the waste collected separately, which played a central role in the Ha Noi 3Rs project.

Some basic knowledge about waste separation from the 3Rs project in Ha Noi city was applied to promote solid waste management for the elementary students in Da Nang city in this study. Since many citizens voluntarily provide food waste to feed pigs in Da Nang city, increasing food waste quality was an important part of this study.

This study aims to evaluate the effects of environmental education to the elementary students, which provides knowledge of solid waste management problems due to improper treatment of waste as well as the benefits of recycling, at the elementary schools in Da Nang City, Vietnam. To achieve the goals, the following objectives were set:

- Conducting a short term MSW management education for the $5^{\text {th }}$ grade students. 
- Examining the effects of school locations and student attributes to the results of the education.

- Comparing two kinds of education methods.

\section{Materials AND Methods}

Surveyed school locations and food residue recycling activities

The surveys were done by questionnaire for elementary school students in two schools in two districts of Da Nang city. School 1 was in the Hai Chau District (HC) that is an urban area and school 2 was far from the center of Da Nang city in the Thanh KheDistrict (TK). Fig. 1 shows the locations of these districts. HC district is well known as the important District in Da Nang City - the city hall, the main theater and the main market are located in this district. TK is farther than HC from the center, and has the second-largest population among the districts in Da Nang city. Table 1 shows the demographics of the two districts. Swine breeding became more popular among farmers in Vietnam during the course of economic growth. Food residue is used for feeding pigs in farms located, in particular, in Hoa Vang Prefecture. This prefecture is located west of the urbanized area in Da Nang. In 2006, the Da Nang People's Committee issued a ban on swine breeding in urbanized areas. As a result, food residue collected from restaurants, hotels, markets, and households in the urbanized area had to be transported to piggeries and boiled well before being served to swine [6]. Many collectors are employees of pig breeding farms. There are intermediate collectors of food residue in urbanized areas as well [7]. A 2011 survey estimated that 26.3 tons of organic waste were recycled every day. This recycling is organized as a business activity without the help of the government [6].

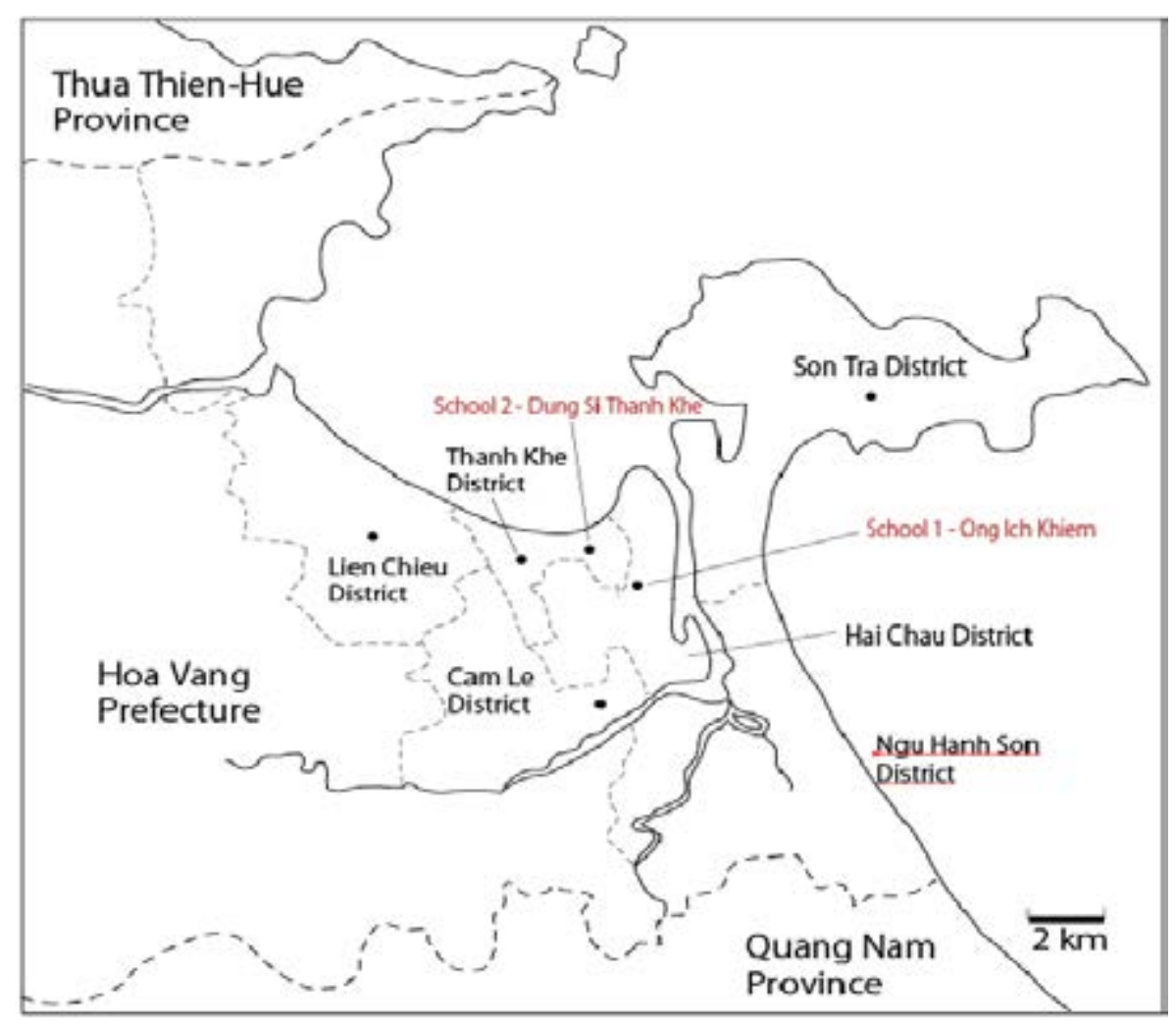

Figure 1: Location of schools surveyed

Table 1

Information about Hai Chau and Thanh Khe districts

\begin{tabular}{|l|l|l|}
\hline & Hai Chau District & Thanh Khe District \\
\hline Area $^{\mathrm{b}}$ & $21.35 \mathrm{Km}^{2}(1.7 \%)$ & $9.36 \mathrm{Km}^{2}(0.7 \%)$ \\
\hline${\text { Population }(2015)^{\mathrm{b}}}^{\mathrm{a}}$ & $208.281(21.9 \%)$ & $184,341(19.4 \%)$ \\
\hline Population density $(2015)^{\mathrm{b}}$ & 8,650 persons $/ \mathrm{Km}^{2}$ & 24,510 persons $/ \mathrm{Km}^{2}$ \\
\hline
\end{tabular}

a. Proportion to the whole city in parentheses

b. Source: General Statistics Office of Da Nang 


\section{Experimental environmental education and questionnaire survey}

The environmental education conducted from 2 to 18 March 2015 provided opportunities for these students to (1) join a waste separation game, (2) learn the present status of voluntary food residue recycling in Da Nang city, and (3) answer the questionnaire survey to assess the impacts of the environmental education. Students were selected randomly from 5 th graders in 2 elementary schools and separated into 2 treatment groups. Treatment group 1 had activities with the games and treatment group 2 had activities without the games.

Figure 2 shows the environmental education poster for elementary student in Da Nang city. This poster contains basic information about organic waste, inorganic waste, and recyclable or reusable waste that follows the guidebook of the 3Rs project in Ha Noi city [16]:

Organic wastes comprise compounds that are readily biodegraded (destruction via natural processes). Mostly plant and animal waste or by-products.
- Inorganic wastes consist of 2 kinds of waste, (1) Inorganic waste, (2) recyclable or reusable waste.

(1) Inorganic waste is not likely to biodegrade under natural conditions or are biodegradable but need very long time such as: glass, porcelain, old cloth, coal, tissue waste, plastic bag, toys and cigarette waste.

(2) Recyclable or reusable waste are not true waste as they can be used again. Materials such as: Cans, bottles, newspapers and cloth.

In addition, the poster contains pictures that show the food waste collection and ecobag systems in Da Nang city. According to the Vietnam Department of Natural Resources and Environment (2011), eco-bags (paper and cloth bags) are bags that can replace plastic bags and are safe for the environment. The poster encompasses concepts of 3R. In Da Nang city, big supermarkets have started to promote and develop eco-bag systems for customers. At the end of environmental education, the students received a notebook the picture of the poster as the cover.

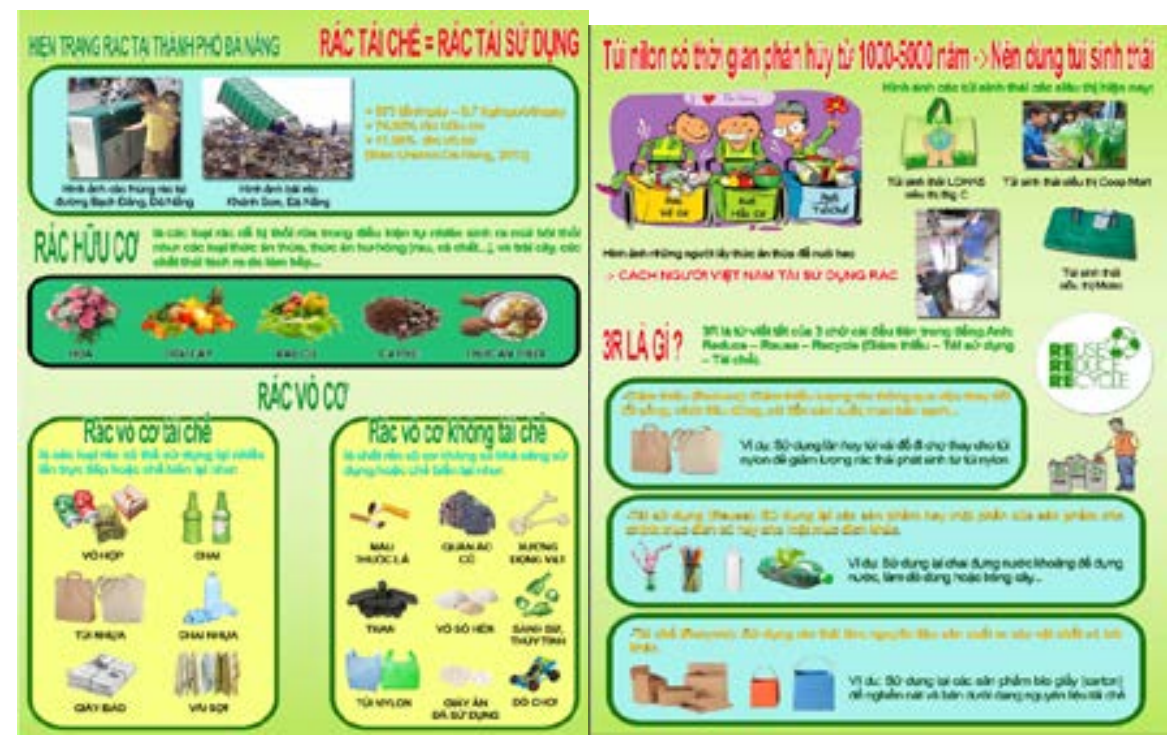

Figure 2: Poster used for environmental education

Figure 3 shows the time schedule of environmental education in the elementary schools that were conducted for 30 minutes in the classroom. Students are separated into 2 treatment groups, treatment group 1 - group with the separation waste game and treatment group 2 without the game. For group 1, the students played the game for 10 minutes at the beginning. The group-2 students studied about typhoon protection for the first 10 minutes. In addition, because the size of the elementary class is from 40 to 50 students, one class was divided into 8 small groups of 5 to 6 students. After the environmental education activity in the class, the students were given an evaluation sheet to score the quality of activities. After 2 days, the students answer selffilling method questionnaire survey-3. 


\begin{tabular}{|c|c|c|}
\hline $\begin{array}{l}\text { Timeline } \\
\text { (Minutes) }\end{array}$ & Treatment 1 & Treatment 2 \\
\hline & \multicolumn{2}{|l|}{ Greeting } \\
\hline & \multicolumn{2}{|c|}{$\begin{array}{l}\text { Make group } \\
-1 \text { group: } 6 \text { students ( } 1 \text { class: } \sim 8 \text { groups) }\end{array}$} \\
\hline & $\begin{array}{l}\text { Short speak about } \\
\text { typhoon }\end{array}$ & $\begin{array}{l}\text { Environment game } \\
\text { - We will make } 10 \text { cards about waste (5 } \\
\text { cards are organic waste, } 5 \text { cards are non } \\
\text { - organic waste). } \\
\text { - Group student will separate cards to dust } \\
\text { box (organic and non - organic waste) } \\
\text { - We will tell student how many card are } \\
\text { they put in right dust box. }\end{array}$ \\
\hline & \multicolumn{2}{|c|}{$\begin{array}{l}\text { Environmental education about solid waste management } \\
\text { We will make teaching material in } \mathrm{A} 0 \text {. We will do the same } \\
\text { teaching for students. }\end{array}$} \\
\hline & \multicolumn{2}{|l|}{ Break time } \\
\hline 30 & \multicolumn{2}{|c|}{ Question time, clean up class and answer check list about activities } \\
\hline
\end{tabular}

Figure 3: Structure of environmental education

Figure 4 and Figure 5 show photos during the environmental education activity in the elementary school in Da Nang City, Vietnam. These are students in school 1 - Treatment group 1 - with the game.

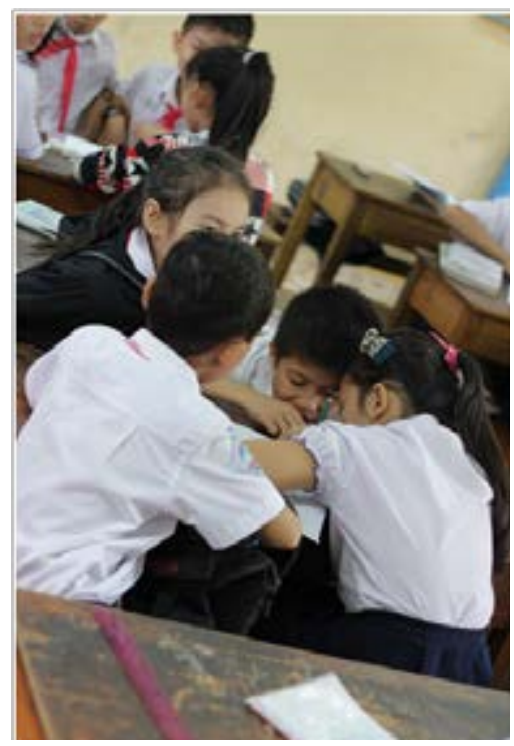

Figure 4: Student attended environmental education game by group work

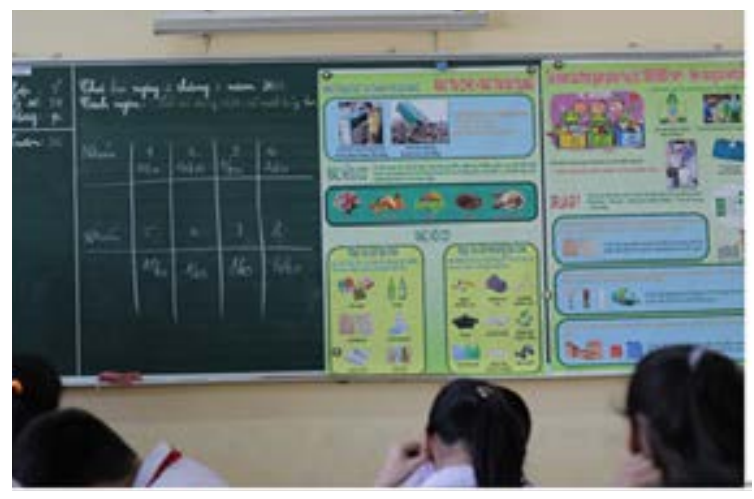

Figure 5 Student answered and environmental education posters

\section{Results AND Discussion}

\section{The different between school 1 and school 2}

Figure 6 shows the student knowledge on the food waste collection system in Da Nang city. The questionnaire required the student to recognize a woman doing a job as shown in the picture in Figure 7. 


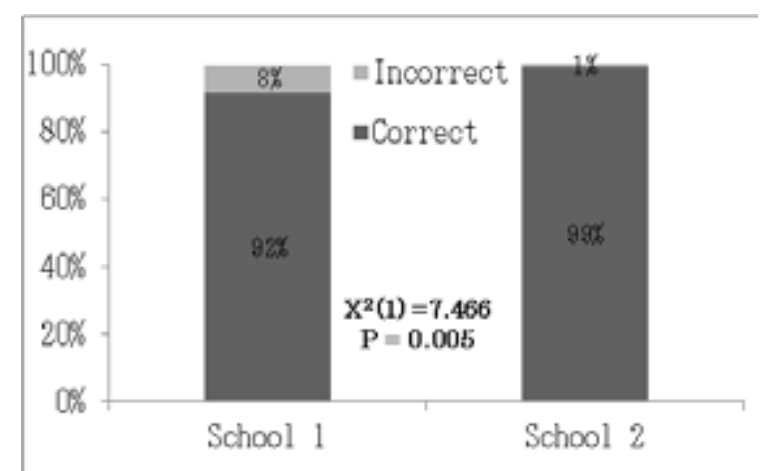

Figure 6 the student knowledge about food waste collection system in Da Nang city between 2 schools

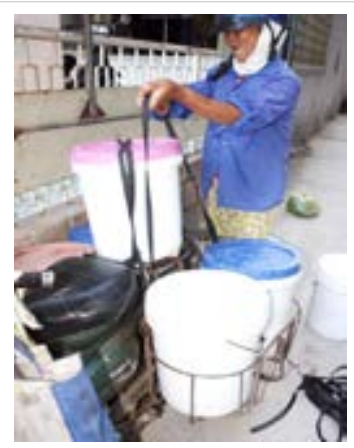

$\square$ Water

$\square$ I don't know

$\square$ Other answer.

The exact chi-square test found a significant difference between school 1 - located in the center of Da Nang city and school 2-located far from the center of Da Nang city. Based on the observation during the study, it was concluded that because school 2 is located near a rural area, the students were exposed to the food waste collection system. On the other hand, school 1 is located in the center of the city where the food waste collection is rarely practiced, the students would not have much exposure to such system.

Figure 8 shows the difference between the student knowledge about the food waste collection system in Da Nang city between 8 classes in 2 Question: Please see picture below and answer the question.

You know what the woman is carrying?

Food waste collection from households and restaurants

Figure 7 Food waste collection in Da Nang city

Note: The checked option is the assumed correct answer.

schools. The exact chi - square test did not find any statistically significant difference between the 4 classes in school 1 and the 4 classes in school 2. Together with questionnaire survey in the 2 schools, observations were made in the classroom, the school and the school environs.

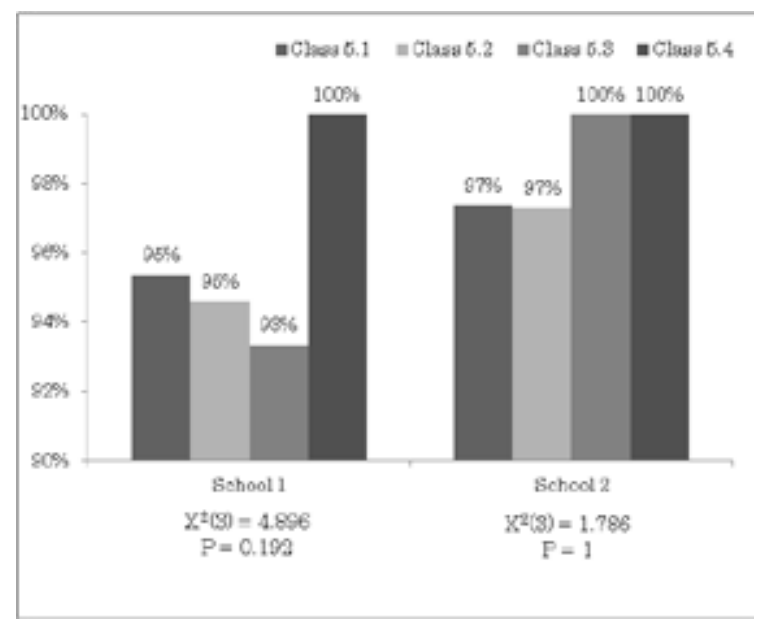

Figure 8 The different of the student knowledge about food waste collection system in Da Nang city between 8 classes in 2 schools.

\section{Students level of interest}

Figure 9 shows the evaluation sheet activity for the students who attended the environmental education activity. Based on the result of this checklist an understanding of students' feelings and ideas about activities could be gathered.

Figure 10 shows the students' interest in environmental education activities. Together with the difference about the student knowledge, the study found a statistical difference in the chi - square test in students' activity evaluation between 2 schools. Students in school 2 had more opportunities to observe the aspects of the food waste collection system that influenced their response to environmental education. It was expected that the society, family and school would affect students' knowledge and behavior. In this case, observed practices in the society had a positive impact on students who participated in environmental education. 
My Feeling About Environmental Education Activities.

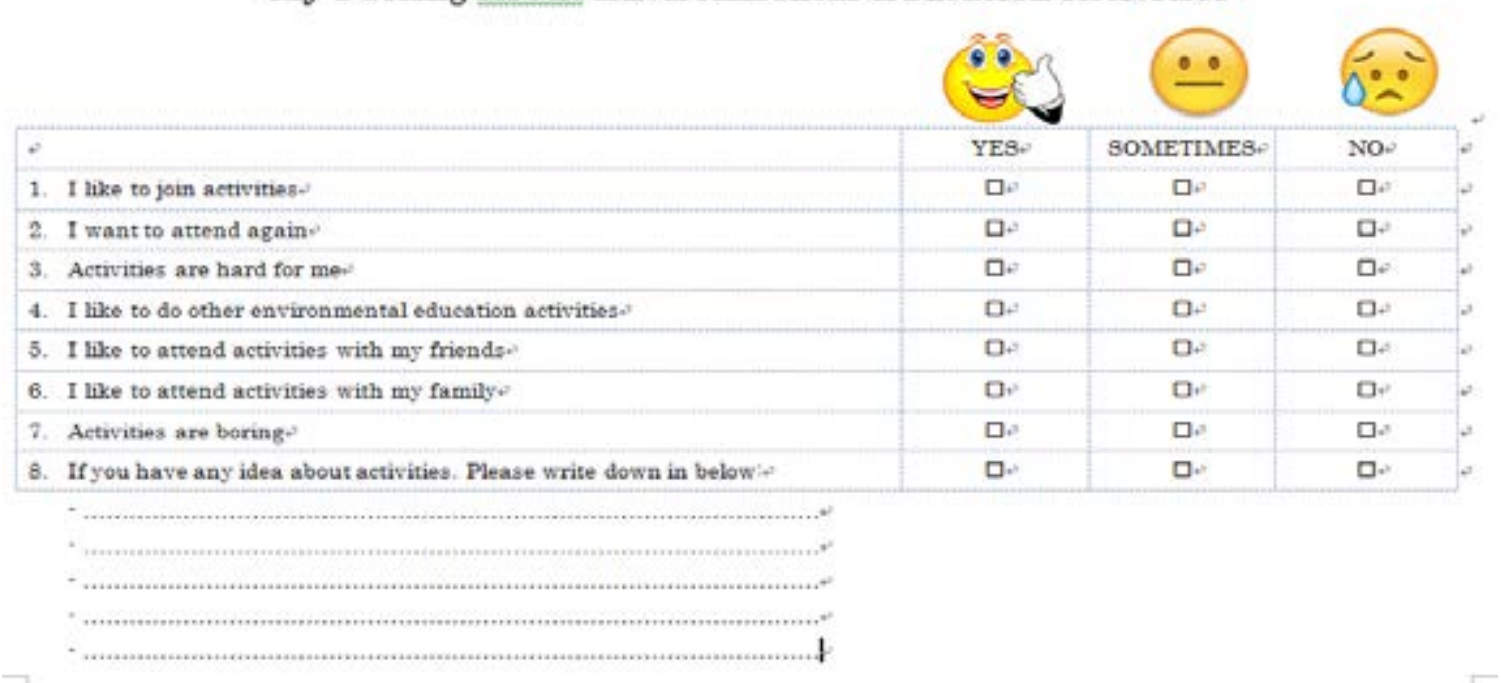

Figure 9 Activity evaluation sheet

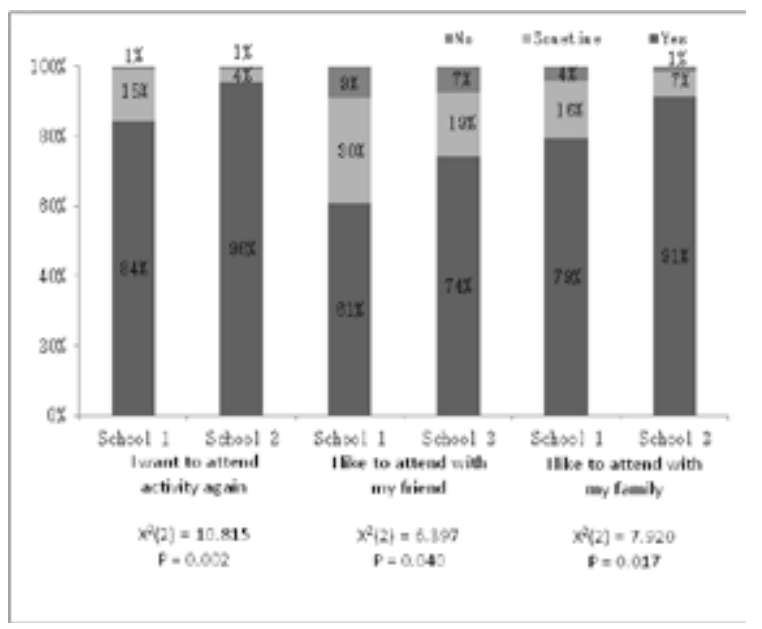

Figure 10 The student interesting in environmental activity.

\section{Difference among classes in school 1}

Figure 11 and Figure 12 show the different students' knowledge on solid waste management after environmental education in school 1 . There was no difference among the 4 classes. The study used the results from 3 questions about organic waste, inorganic waste, and recyclable or reusable waste. The questions below show the content of environmental education from March 2015. The food waste collection systems showed the impact of the society on the students' knowledge and behavior when they attended environmental education. But that question could not show any difference between classes on school. To access the knowledge gained from the environmental education the students have received and to identify any differences between classes, the students were asked the 3 questions below. The bolded response is the correct answer to each question.

\begin{tabular}{l}
\hline Question 1: Which is the best answer to describe the organic waste? \\
Flower, fruit, tea waste, food waste, leaf, vegetables, coffee waste. \\
$\square$ Fruit, tea waste, food waste, leaf, vegetables, coffee waste. \\
$\square$ Flower, fruit, leaf, vegetables, coffee waste. \\
$\square$ I do not know \\
Question 2: Which is the best answer to describe the inorganic waste? \\
Plastic bag, bone, toy waste, tissue paper, old cloth, tree brand, seashell, \\
coal, glass \\
$\square$ Plastic bag, tissue paper, old cloth, tree brand, seashell, coal, glass \\
$\square$ Plastic bag, bone, toy waste, tree brand, seashell, coal, glass \\
$\square$ I do not know \\
Question 3: Which is the best answer to describe the recyclable or reusable \\
waste? \\
Can, bottle, recycle bag, news paper. \\
$\square$ Can, bottle, news paper. \\
$\square$ Can, recycle bag, news paper. \\
$\square$ I do not know
\end{tabular}

These waste categories were referred to the ones used in the 3Rs project in Ha Noi city (UNDP, 2013). Since this study focused on increasing the quality of food waste to be used as pig feed, the category of organic waste in this study excluded some items from that of Ha Noi's such as: eggshell, fertilizer, and animal body.

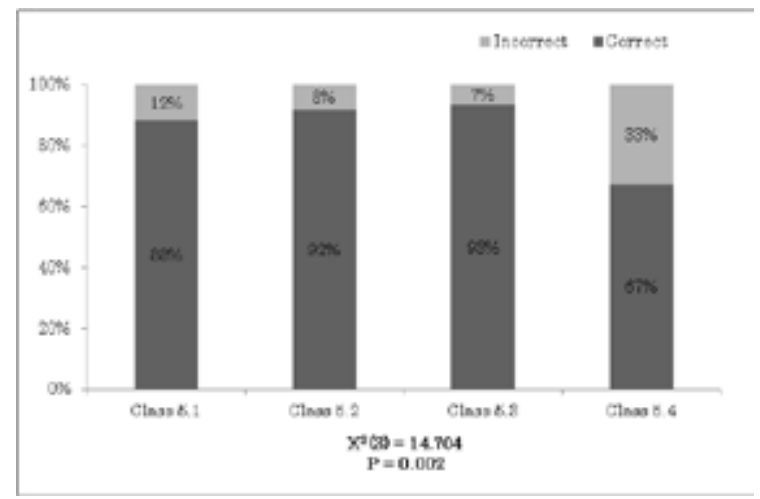

Figure 11: The student knowledge about inorganic waste in school 1 


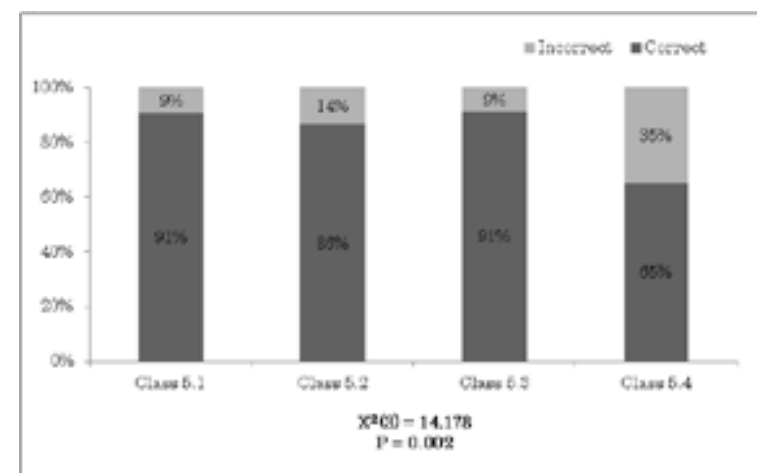

Figure 12: The student knowledge about recyclable and reusable waste in school 1

The chi - square test found significant statistical differences between the students of 4 classes in school 1 . The study found 2 reasons for the differences between 4 classes in school 1 .

- The class 5.4 in school 1 was the first class where environmental education was introduced.

- In addition, only in classes 5.1 and 5.3 of school 1 , a supervisor was present in the class. The presence of other teachers can have a positive impact on students when they attend environmental education activities.

\section{Gender differences}

Gender comparison is an interesting topic in many types of research. Male and female students differ in their preferences for learning that involving active manipulation versus inactive learning, working with others or alone, working independently or with teachers' guidance and instruction, and using numbers, logic, and computers [19]. Compared to females, males prefer learning environments that involve: working independently, actively manipulating materials, and using numbers, logic, and computers [19].

Figure 13 showed the interest of male and female students in environmental education. The result found that the male and female students had different levels of interests when they attended environmental education. In addition, the chi square test did not find any statistical difference between male and female students in individual school 1 or school 2. Figure 10 shows that the female students had more interest in environmental education than male students.

According to the results from Kato et al [7] where $79.6 \%$ of the respondents were female, in Vietnamese culture, females are more responsible for household work than males. Therefore females have the responsibility of disposing the food waste. This, by extension, is indicative of female students being more focused and interested in environmental education.

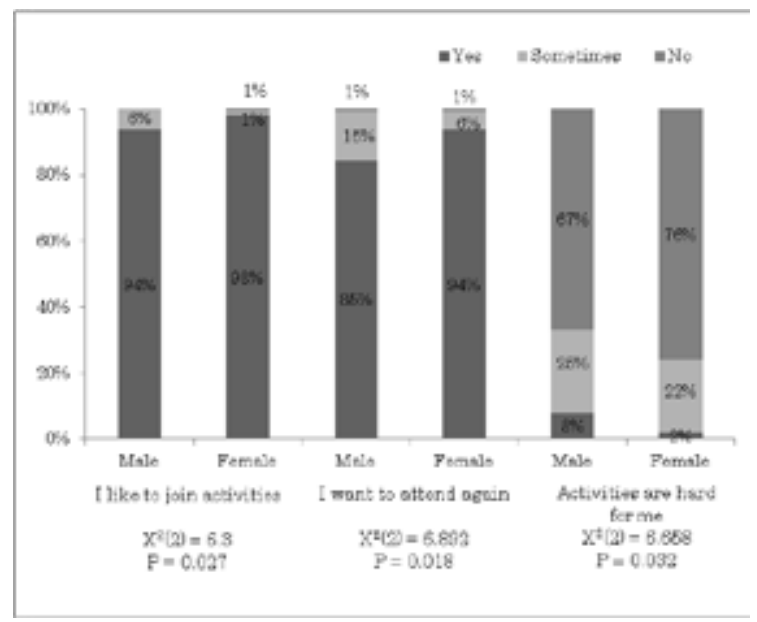

Figure 13 Male and female interesting in environmental education

\section{The different between 2 treatment groups}

Figure 14 showed the students' knowledge on organic waste, inorganic waste, and recyclable or reusable wastes in the 2 treatment groups. The exact chi - square test did not find any significant statistical difference between treatment group 1 (with the game) and treatment group 2 (without the game).

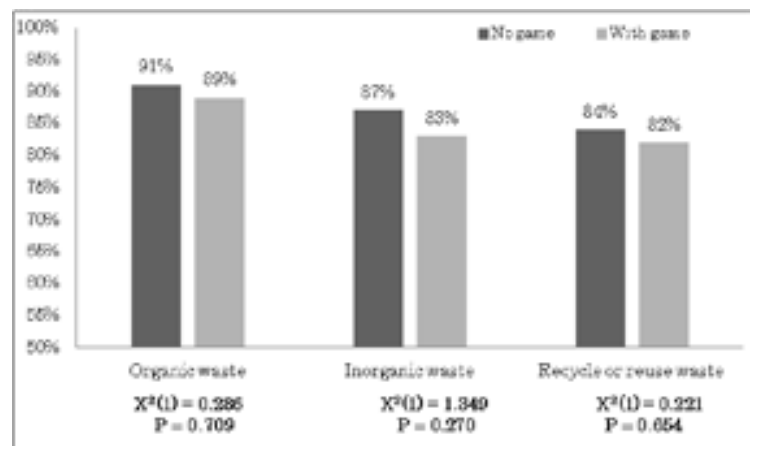

Figure 14 The student knowledge about solid waste management after environmental education in school

Figure 15 shows the students' responses in the 2 treatment groups with environmental education. The chi - square test did not find any significant statistical difference between treatment group 1 (with the game) and treatment group 2 (without the game). Thus, the results were pooled together between 2 groups. From the groups, 89\% of the students said that they wanted to attend the activities again. Furthermore, $66.5 \%$ want to attend activities with friends, and $85 \%$ want to 
attend activities with their family.

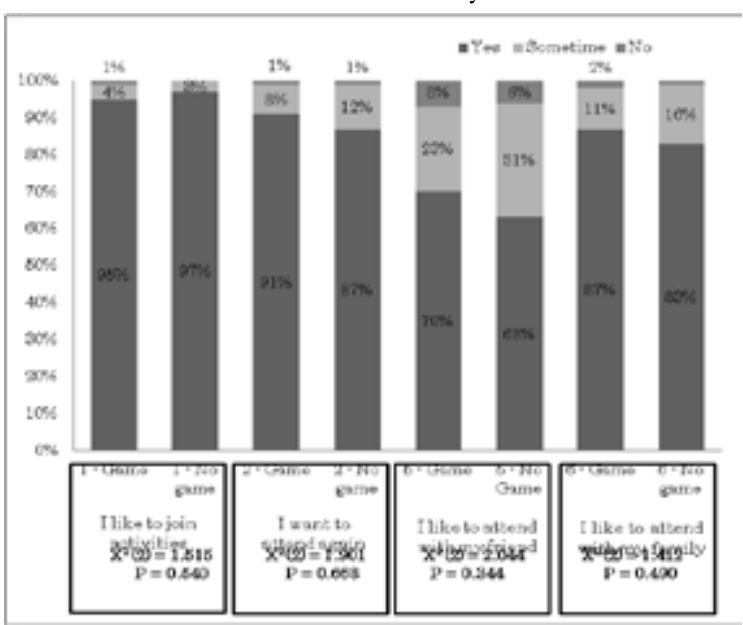

Fig. 15: Activity evaluation by students

The study expected that the environmental education with the game had a good impact on the students. The results show that the environmental education with the game had the same impact as environmental education without the game. Some possible reasons for this may be:

- The game time was too short (10 minutes / class for game activity).

- The environmental education was conducted only once.

- The students did not have any opportunity to practise what they have studied.

- The game activity was easy for students and therefore the students lack interest in the game.

\section{Conclusions}

This study has provided a detailed description of the environmental education for the elementary students in Da Nang City, Vietnam especially focusing on the solid waste management.

It was indicated that the students were equipped with useful information about solid waste after the environmental education. The students were interested in the environmental education in school where $96 \%$ of the students preferred the educational activities and $89 \%$ of the students wanted to attend the activities again. The society around the student can provide impact to the student when they participate in environmental education. From school 2, 99\% of the students answer correctly on food waste collection questions compared to $92 \%$ from school 1 . In the addition, the difference between the students' gender will be a challenge in environmental education at the elementary school level. Environmental education needs to get more involvement from the male students.

The study reveals that certain strategic constraints of the environmental education conducted by the authors. This was done only once, and the grades/marks obtained in the education were not counted in the score of the students. Due to this reason, the activities might not be taken seriously to change the students' actual behavior. Since Da Nang city does not have an official source separation policy of MSW, it is not possible to observe the students' behavioral change.

Although significant progress toward achieving universal primary education has been made over the past decade, out-of-school children (OOSC) remain a pervasive global problem. According to UNESCO Institute for Statistics [23], there are nearly 58 million OOSC of primary school age in the world; 7 million of them are in East Asia and the Pacific (EAP). In Vietnam, 2012-2013 had $98.31 \%$ children who went to the elementary schools, but only $92.25 \%$ of them who continued to middle school [18]. The rates of OOSC on primary education are high in Southeast Asia: Indonesia 6\%, Thailand 4\% and Cambodia $14 \%$ [17]. The rate of continuation to secondary school in some Southeast Asia countries is lower than 96\%: Cambodia 80\%, Thailand $95 \%$ and Indonesia $96 \%$ [17]. It is important to conduct environmental education from the elementary school for a long-term sustainable development.

In future research, we will continue to make environmental education activities for the elementary school students. The objective of that research is to identify effective methods to increase the students' knowledge on the environment and particularly solid waste management.

\section{ACKNOWLEDGEMENT}

This work was supported by KAKENHI Grant Number 25303006 provided by Japan Society for the Promotion of Science.

\section{REFERENCES}

Asia-Pacific Economic Cooperation (APEC). (2015). Policy review for low-carbon town development project in Da Nang, Viet Nam, report for the APEC energy working group, APEC, Singapore; http://aperc.ieej. or.jp/publications/reports/lcmt/LCMT_ 
Phase_3_Da_Nang_Viet_Nam_Policy_ Review_Report_Final.pdf; 2014. (accessed Dec 23, 2015)

Central Intelligence Agency (CIA). (2014). The World Factbook, East \& Southeast Asia: Vietnam, https://www.cia.gov/library/ publications / the-world-factbook/geos/ vm.html, 2014. (accessed Dec 23, 2015)

Grossman, H., \& Grossman, S. (1994). Gender Issues in Education. Boston, MA: Allyn and Bacon,.

http://www.unep.or.jp/ietc/SPC/news-jul10/ JICA_(Ms.Kawata).pdf (accessed Dec 23, 2015)

Human Resources and skills Development Canada. (2011). Public Investments in Early Childhood Education and Care in Canada, Quebec: Human Resources and skills Development,

Kato, T., Pham, T. X. D., Hoang, H. Xue, Y., and Tran, V. Q. (2012). Food residue recycling by swine breeders in a developing economy: A case study in Da Nang, Viet Nam. Waste Management, , 32(12): 2431-2438.

Kato, T., Tran, A. Q., and Hoang, H. (2015). Factors affecting voluntary participation in food residue recycling: A case study in Da Nang, Viet Nam. Sustainable Environment Research, , 25(2), 93-101.

Kato, T., Tran, A. Q., and Hoang, H. (2016). Waste generation in traditional organized bazaars: A case study of organic waste sources in $\mathrm{Da}$ Nang City, Viet Nam. Journal of Material Cycles and Waste Management; (in press).

Kawata, A. (2010). JICA cooperation for SWM and $3 \mathrm{R}$ in Asia with special reference to WEEE/E-waste management, Regional workshop on WEEE/E-waste management, July 6-9, Osaka Japan.

Learning and Ecological Activities Foundation for Children (LEAF), Activity Report http:// leaf.or.jp/e120actionreport.pdf, (2004) (accessed Dec 23, 2015)

Milan, T., Nicholas, B., the Economic cost of out-of-school children in Southeast Asia (2015). Bangkok, Thailand: United nations educational, scientific and cultural organization, 7;

Ministry of Education \& Training . (2014). Báo cáo quôc gia - Giáo duc cho moi nguoi 2015 cua Vietnam (National Report - 2015
Education of Vietnam), Ha Noi, Vietnam: Ministry of Education \& Training,

Ministry of Natural Resources and Environment. (2011). Báo cáo môi truông quôc gia; Chât thâi răn (Vietnam Environment report 2011: Solid waste management), Ministry of Natural Resources and Environment, Ha Noi, Vietnam; 2011.

Nguyen, D. A. (2013). Report on current situation and orientation of solid waste management in Da Nang city, Department of Natural Resources and Environment, Da Nang, Vietnam, http://hls-esc.org/ documents / 4hlsesc/1A\%20-\%20Da\%20 Nang.pdf; 2013 (accessed Dec 23, 2015)

Sasaki, S. (2006). Better Practice of Waste Management in Thailand, United Nations Environment Programmed, Bangkok, Thailand.

Taniguchi, T., Yoshida. (2011). M., Public involvement and mobilization for promoting 3R initiative in Hanoi City: Lessons from 3R initiative project in Hanoi City 2006-2009, Proceedings of the 8th Expert Meeting on Solid Waste Management in Asia and Pacific Islands, February 21-23, 2011, Tokyo, pp.1-8.

Thanh, N., P., Matsui, Y. (2011). Municipal solid waste management in Vietnam: Status and the strategic actions, International Journal of Environmental Research, 2011, 5(2): 285-296,

United Nations Development Programme (UNDP). (2013). Sô tay huông dân thu gom và xu lý rác hô gia đình (Guider book for collection and treatment household waste), UNDP, Ha Noi, Vietnam http:// recerd.org.vn/vi/an-pham/so-tay-huongdan-huong-dan-thu-gom-va-xu-ly-rac-hogia-dinh ,. (accessed Dec 23, 2015).

United States Agency for International Development (USAID). (2006). Comparative Assessment: Community Based Solid Waste Management (CBSWM): Medan, Bandung, Subang and Surabaya, Environmental Services Program, Jakarta, Indonesia;

University of Gothenburg (2008). The Gothenburg Recommendations on Education for Sustainable Development, Gothenburg: University of Gothenburg, Sweden. 